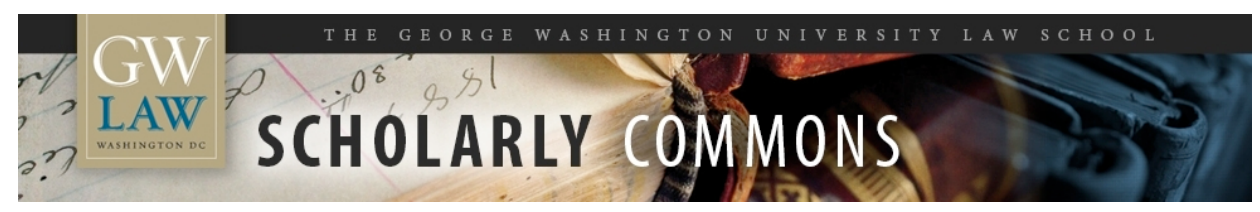

\title{
Competition Agency Design: What's on the Menu?
}

William E. Kovacic

George Washington University Law School, wkovacic@law.gwu.edu

David A. Hyman

Follow this and additional works at: https://scholarship.law.gwu.edu/faculty_publications

Part of the Law Commons

\section{Recommended Citation}

Kovacic, William E. and Hyman, David A., "Competition Agency Design: What's on the Menu?" (2012). GW Law Faculty Publications \& Other Works. 628.

https://scholarship.law.gwu.edu/faculty_publications/628

This Article is brought to you for free and open access by the Faculty Scholarship at Scholarly Commons. It has been accepted for inclusion in GW Law Faculty Publications \& Other Works by an authorized administrator of Scholarly Commons. For more information, please contact spagel@law.gwu.edu. 


\title{
COMPETITION AGENCY DESIGN: WHAT'S ON THE MENU?
}

\author{
William E. Kovacic \& David A. Hyman ${ }^{*}$
}

\begin{abstract}
:
In recent years the United Kingdom and various other countries have decided to restructure the institutions responsible for enforcing competition laws. How should a nation choose among myriad alternative arrangements? This paper lays out nine major institutional choices that governments must address in designing the implementation mechanism for a competition law. The paper discusses tradeoffs associated with each choice and examines interdependencies among different design elements. In doing so, the paper offers a structured framework that countries can use in forming new competition systems or altering existing institutional arrangements.
\end{abstract}

\section{Introduction}

In November 2010, the United Kingdom's Ministry of Business, Innovation, and Skills (BIS) began an inquiry to explore a fundamental redesign of the country's system of competition law. ${ }^{1}$ Among other measures, the initiative contemplated the dissolution of the Office of Fair Trading (OFT) and Competition Commission (CC) and creation of new mechanisms to implement the law. At some time in the next few years, the UK is scheduled to establish a new Competition and Markets Authority (CMA) to perform functions previously assigned to the predecessor bodies. ${ }^{2}$

The decision to retool the UK system is noteworthy for at least two reasons. Firstly, the new regime will replace a system widely regarded to be one of the world's best. A combination of legislative reforms, inspired leadership, and excellent staffing had advanced the UK to the front ranks of

\footnotetext{
* Kovacic is the Global Professor of Competition Law and Policy at the George Washington University Law School. Hyman is the Ross \& Helen Workman Chair in Law and Professor of Medicine, University of Illinois. We are grateful to the participants in the University of Newcastle conference for many useful comments and suggestions.

${ }^{1}$ Dep't for Bus. Innovation \& Skills, Government launches growth review (Nov. 29, 2010), available at http:/www.bis.gov.uk/news/topstories/2010/Nov/government-launchesgrowth-review

${ }^{2}$ The proposal to create the CMA is examined in Peter Freeman, Beware the Ides of March - The Government's Proposed Competition Reforms, _ European Competition J. (2012).
} 
the more than 120 jurisdictions that have competition laws. ${ }^{3}$ Governments ordinarily do not tear down and rebuild truly superior mechanisms, especially when the measures that achieved greatness are relatively new. To take the risks that come with such a drastic renovation makes sense only if the new regime promises marked improvements upon the performance of its already distinguished predecessor.

The second striking aspect of the reforms is the manner of their creation. With little advance deliberation, BIS launched the initiative with the stated aims of simplifying public administration and reducing the costs associated with maintaining multiple institutions to perform similar or related policy functions. The UK government's pledge to pursue basic changes imparted considerable momentum for BIS to propose a wholesale makeover. Yet the decision to begin the inquiry and the deliberations in the reform process do not appear to have been informed by any overarching framework to consider the value of specific adjustments to the UK's competition policy institutions.

The question of how to design or reform institutions for the implementation of competition laws is not merely a parochial concern of the United Kingdom. Recent years have featured major reforms around the world. ${ }^{4}$ France, Portugal, and Spain have combined two existing competition agencies into one. Brazil recently folded its three competition bodies into a single new institution. The Netherlands is poised to combine its regulators responsible for competition law, consumer protection, and the postal and telecommunications sectors into a new body. Spain is considering a further step of unifying the competition agency with as many as six separate sectoral regulators. Other countries have experimented with various institutional reforms including adding and subtracting policy functions, creating new quality control mechanisms, and enhancing reliance on multinational enforcement networks. Finally, other countries have modified substantive competition law (e.g., adding criminal penalties and enhancing private rights of action), which will predictably affect the institutional dynamics in which competition agencies operate.

In this paper we step back from the details of these individual case studies, and lay out the implicit "menu" that countries are choosing from in designing and/or reforming their competition agencies. Part I explains the logic of focusing on "engineering not physics" and then identifies nine

\footnotetext{
${ }^{3}$ For example, OFT and the $\mathrm{CC}$ consistently receive high marks in the annual survey of antitrust enforcement conducted by the Global Competition Review. See Global Competition Review, Rating Enforcement - The Annual Ranking of the World's Leading Competition Authorities 137-44 (June 2012) (reviewing OFT and the CC).

${ }^{4}$ These are described in William E. Kovacic, The Institutions of Antitrust Law: How Structure Shapes Substance, 110 Mich. L. Rev. 1019, 1042-43 (2012).
} 
major institutional design choices that influence the quality and effectiveness of competition agencies. We discuss the trade-offs associated with each choice, and review the inter-relationships among individual choices. Part II briefly considers the implications of these dynamics for the future of agency design and competition policy. 


\section{Agency Design: Choices and Consequences}

\section{A. The Logic of "Engineering Not Physics"}

This essay focuses on the "engineering" of agency design and implementation, rather than the "physics" of substantive policy development. ${ }^{5}$ Our topic does not attract much in the way of academic attention or interest; as Professor Peter Schuck has observed:

It is the substantive merits and politics of policy proposals that almost always dominates public debates, not the often invisible, mundane processes of public administration. Even political scientists, who should know better, tend to relegate public administration to a relatively obscure corner of their profession. Whereas the substance of policy design is considered sexy, the process of policy administration is usually seen as, well, boring. ${ }^{6}$

Even if our topic is, well, boring, we are convinced that it requires more attention than has historically been the case. Competition law assuredly presents fascinating questions of doctrine and high theory - but as one of us noted in an earlier article

to affect policy, theory cannot be suspended in air. If theory is not grounded in the engineering of effective institutions, it will not work in practice. The engineering of policy making involves basic questions of implementation. It is one thing for the policymaking aerodynamicist to conceive a new variety of aircraft. It is another for the policy engineer to design and build it. To have elegant physics without excellent engineering is a formula for policy failure."7

\footnotetext{
5 William E. Kovacic, The Digital Broadband Migration and the Federal Trade Commission: Building the Competition and Consumer Protection Agency of the Future, 8 J. Telecom. \& High Tech. L. 1, 5 (2010) ("The physics of substantive policy routinely eclipses the engineering of implementation.")

${ }^{6}$ Peter H. Schuck, Is a Competent Federal Government Becoming Oxymoronic? 77 George Washington L. Rev. 973, 975 (2009).

${ }^{7}$ Kovacic, supra note 4 , at 5.
} 
In another article, drawing from examples across the U.S. government and over time, we provide a wide-ranging analysis of the impact of agency design on agency behavior. ${ }^{8}$ This far-shorter essay represents our first cut at the issues raised by the design of competition agencies. Although we use the BIS proposal as a spring-board, our analysis goes well beyond the issues raised by the proposal on the table to fold OFT and $\mathrm{CC}$ into CMA.

\section{B. What's on the Menu?}

\section{Autonomy v. Accountability}

The establishment of a competition agency requires decisions about its relationship to elected officials in the executive and legislative branches of government. Ideally, the agency will be simultaneously autonomous from political pressure in exercising its authority to investigate infringements and prosecute violations, but accountable for the exercise of its powers and expenditure of public resources. Various design choices influence the degree to which these two (admittedly somewhat inconsistent) goals are met.

One common approach to achieving autonomy is to establish the competition authority as an "independent" agency." In this model, the agency's leaders are given fixed-term appointments, and they may be removed only for good cause. Funding may also be a source of autonomy if the agency can obtain resources without recourse to ministerial approval or legislative appropriations. For example, the agency might collect and retain user fees as part of the merger review process. Agency autonomy is also enhanced when courts must give deference to its judgments about facts and/or law.

Accountability can be achieved in various ways, some of which involve design features that reduce autonomy. The agency might be constituted as an executive branch ministry or subunit of another ministry, and its leaders would serve at the pleasure of the head of state or the legislature. Accountability is usually established by giving the executive branch and/or the legislature direct control of the agency's budget. For example, the agency's budget proposals have to be approved by a central executive branch body and/or funded through a specific legislative appropriation every year.

\footnotetext{
${ }^{8}$ David A. Hyman \& William E. Kovacic, Government Organization/Reorganization: Why Who Does What Matters (forthcoming, 2013).

9 The possible meanings of "independence" and the tensions between autonomy and accountability are discussed in William E. Kovacic, Competition agencies, independence, and the political process, in Competition Policy and the Economic Approach - Foundations and Limitations 291 (Josef Drexl, Wolfgang Kerber \& Rupprecht Podszun eds. 2011).
} 
Another accountability strategy is to mandate fuller disclosure about the agency's activities. For example, an agency might be required to publish regular reports about the agency's activities and operations. A jurisdiction can establish a freedom of information act that compels the agency to disclose certain types of information in response to requests by the public. The agency also can take voluntary measures to increase accountability, including the revelation of data not required by law, frequent public appearances by agency leaders to explain and defend policy choices, and public consultations in which the agency seeks views about what it should do. As its powers increase, an agency may find that expanded voluntary disclosure is necessary to increase its perceived legitimacy.

Autonomy and accountability are not goals to be sought in their own right. An agency that is completely autonomous (e.g., with tenured appointments and a separate income stream) can become isolated from the policy decisions that shape the competitive process. For example, the agency might find itself on the outside looking in as executive branch ministries and legislatures hammer out legislative packages that will affect the competition more deeply than any ten cases the antitrust agency might file. Similarly, an agency that is "too accountable" may spend so much time responding to legislative demands/oversight, and public inquiries that it is hamstrung.

\section{Leadership Structure: Multi-member board or unitary executive?}

Competition agencies typically adopt one of two dominant models for their leadership structure: either a multi-member board or a unitary executive. A majority of the world's competition agencies are governed by multi-member boards. By custom or by statute, many countries require that the board's membership to be politically heterogeneous. The multimember board is believed to offer the advantages of diversified expertise, greater resistance to capture, and heightened legitimacy. Multi-member boards are also less subject to abrupt shifts in policy in the wake of an election that results in a change in power.

A unitary hierarchy offers its own advantages. Compared to a board whose members may communicate disparate views about what their agency should do, a single executive is better able to create a clear "brand" and define a coherent program for her agency. A single executive is more likely to quickly reach a decision and implement it than a multi-member board. Finally, because decision-making is in the hands of a single individual, it less likely the slot will go to an unqualified political supporter. 
Regrettably, the same cannot be said of the multi-member board model. ${ }^{10}$

Hybrid models are relatively uncommon, but do exist. For example, the OFT is headed by a chairman and a chief executive officer, who are advised by an external board. The OFT top officials are not bound by the advice of the external board, but the OFT's custom has been to rely heavily on the board for guidance about substantive programs, individual initiatives, and matters of administration. Whether this approach can be employed in other jurisdictions depends on the legal status and permissibility of such advisory bodies.

The issue of optimal leadership structure is a policy perennial, which has bedeviled presidents, legislators, agency heads, generals, admirals, and scholars since the beginning of time. It is hard to improve on the advice proffered by Professor Richard Thaler when the Consumer Financial Protection Bureau was being established: "Above all, I'd urge the head of this agency to devise rules under the assumption that, someday, he or she will be succeeded by a nitwit."11

\section{Stand-Alone Agency or Subsidiary?}

Most jurisdictions have established the competition agency as a distinct, stand-alone body. A self-contained body has greater ability to establish a distinct identify and brand. The separate agency also can respond to changing circumstances without the need to "run things up the ladder," or to coordinate policy with other units in the organization of which it is one part.

Alternatively, the competition agency can be situated within a larger entity. This is the model used by the European Union (where the Directorate General for Competition is but one of 27 directorates of the European Commission, and by the United States (where Antitrust is one of 8 Divisions, five Bureaus, 27 Offices, 4 Programs, 2 Commissions, and 2 Institutes of the Department of Justice). ${ }^{12}$ The competition agency benefits from the reputation and political power of the larger entity, but it must compete with other units for budgetary resources and administrative support. It is also more difficult to create a distinct, respected identify amidst a sea of sister subsidiaries.

\section{One or Many Enforcement Agencies/Agents?}

Who should enforce a nation's competition laws? The simplest model

\footnotetext{
${ }^{10}$ See William E. Kovacic, The Quality of Appointments and the Capability of the Federal Trade Commission, 49 Admin. L. Rev. 915 (1997).

${ }^{11}$ Richard Thaler, Level Playing Fields, in Soccer and Finance, N.Y. Times BU5 (July 25, 2010)

12 United States Department of Justice Agencies, available at http://www.justice.gov/agencies/index-list.html
} 
is to give a single public institution exclusive enforcement authority. More pluralized models come in various flavors. Consider the range of structural models adopted by the United States. A nation can establish two or more public enforcement agencies at the same level of government (e.g. giving the FTC and DOJ Antitrust Division shared authority over mergers); it can give enforcement power to agencies at multiple levels of government (e.g., both the federal government and individual states can enforce the federal antitrust laws); it can limit enforcement authority to antitrust-specific entities, or responsibility can be shared with sectoral regulators (e.g., the Federal Communications Commission's shared competence with DOJ for combinations of telecommunications providers); and it can limit enforcement authority to government actors or deputize private actors by creating a private right of action.

Reliance on multiple enforcement agencies serves several distinct purposes. It provides insurance against the possibility that any single agent will fail to execute its responsibilities by reason of sloth, resource constraints, corruption, capture, or political influence. Multiplicity also creates the basis for rivalry that can lead to improvements in system-wide performance. Multiple agents allow testing of alternative approaches to implementation - as with the establishment in the United States in 1914 of an administrative commission (the FTC) to supplement the work of an existing executive branch enforcement body (DOJ). ${ }^{13}$

Multiplicity also has its costs. The placement of two or more public agencies in the same policy domain is almost certain to create tension among the institutions, each of which will strive to achieve preeminence and greater appropriations. Such rivalry can readily degenerate into competition on margins that do not increase society's well-being, but instead focus on the parochial interests of the institutions.

Multiplicity can also detract from the coherence of a nation's competition policy. As the number of enforcement agents increases, no single agent may have the ability to determine the selection and timing of important litigation matters. Ill-advised prosecutorial choices by one agent may yield doctrines that adversely restrict the capacity of other agents. Multiplicity will also impede the ability of a jurisdiction to speak with one voice in international fora.

There are various strategies to address the problems created by multiplicity, ranging from hard constraints that establish a strict hierarchy of authority (such as the power of the European Commission to displace the authority of national competition authorities on matters with broad community-wide significance) to the use of "soft law" approaches (such as

\footnotetext{
${ }^{13}$ See William E. Kovacic, Downsizing antitrust: is it time to end dual federal enforcement?, 41 Antitrust Bull. 505 (Fall 1996).
} 
the operation of the European Competition Network).

\section{Single-Purpose or Multi-Purpose?}

Some nations have created single-purpose competition authorities, whose sole remit is the enforcement of antitrust commands while a majority of other nations have formed multi-purpose institutions that also enforce other bodies of law. The most common combination is antitrust plus consumer protection statutes and/or public procurement laws, but more exotic combinations exist.

Single-purpose agencies have greater capacity to establish a clear institutional "brand" and coherent policy priorities that readily can be communicated, but multi-purpose agencies can realize synergies and lower the costs associated with coordinating policy between separate institutions with related functions. These synergies will only exist if the functions to be combined are true policy complements and do not consist of a rubbish bin of dissimilar (or, worse, conflicting) duties. The greater the diversity of functions, the lower the synergies - and harder time a multi-purpose agency may have in persuading a reviewing court that it is genuinely expert and entitled to deference in all the policy domains assigned to it.

A multiplicity of functions does provide a safeguard against capture. Owing to the breadth and diversity of its duties, a multi-purpose agency provides a more elusive target for any single industry group. To be sure, most competition agencies have regulatory authority over a broad array of industries and firms, and these cross-cutting commercial interests provide a built-in buffer against capture.

\section{Law Enforcement or Competition Policy?}

Countries differ in whether the competition agency is accorded a narrow or more expansive ambit. A narrow conception of the agency's role emphasizes its law enforcement functions (e.g., conducting investigations and prosecuting infringements of the law). A broader conception of the agency's role allows it to function as an advocate for competition (e.g., by performing studies and appearing before other government bodies to urge them to consider the importance of promoting competition when adopting policies). This advocacy role makes it possible for the agency to protect the marketplace from public restraints on competition, which are likely to be more durable than private restraints.

"Advocacy" authority will expand the competition agency's field of play but doing so has important political consequences. When an agency is seen to be performing only law enforcement functions, elected officials will pay a political cost for interfering. Conversely, when an agency engages in advocacy activities, it will be seen as fair game by the ministers and 
legislators being lobbied - and they will reasonably respond by attempting to influence the agency's priorities, preferences, and funding.

Stated differently, advocacy entails forays into matters that elected officials regard as their policy domain. An agency that enters political neighborhoods can expect to face greater buffeting than it encounters when it prosecutes a case in the courts.

\section{Remedies: What's in the Toolkit?}

Should violation of a nation's competition laws constitute civil offenses, crimes, or both? The enhancement of sanctions can increase the competition agency's credibility and its ability to deter violations. But, ratcheting up sanctions will have institutional side effects. Most nations reserve the authority to prosecute crimes to an executive branch department, such as a ministry of justice or an office of the public prosecutor. If competition enforcement is vested in an independent administrative agency, bringing a criminal case will require collaboration between the agency (which usually performs the investigation) and the prosecutor (who decides whether to file the criminal case). Differences of opinion are likely, but cooperation is necessary if promises of leniency made by the competition agency are to be credible and effective.

\section{Internal Design}

How should the competition agency be organized internally? Although there are multiple variations, the obvious possibilities are by professional training (e.g., lawyers in one bureau, and economists in another); by substantive body of law being enforced (e.g., separate bureaus for antitrust and for consumer protection); or by line of business (e.g., separate units for health care, transportation, and media). Of course, various hybrid arrangements are possible as well. There is also variation in the design of the veto-gates through which information, recommendations, and decisions must flow.

These internal design features can have real consequences. For the first forty years of its existence, the FTC put attorneys and economists in separate bureaus. ${ }^{14}$ From 1954 to 1960, it combined attorneys and economists into a single bureau. In 1960, it switched back to separate bureaus, and has followed that approach ever since. As a contemporaneous account reflected, prior to the merger, "the economists . . . disagreed vehemently with the economic approach being taken by the legal division, and the lawyers wanted greater control over the economists." 15 Combining

14 See Luke M. Froeb, Paul A. Pautler \& Lars-Hendrik Roller, The Economics of Organizing Economists, 76 Antitrust L.J. 569 (2009).

${ }^{15}$ See Willard Mueller, Fed. Trade Comm'n, Remarks for Bureau of Economics 
the economists and lawyers into a single bureau meant that the economists reported to the lawyers - which meant that the views of the lawyers invariably prevailed, irrespective of whether they represented sound economics or not. Separate bureaus helped allow both perspectives to be presented to decision-makers, and ensured that disciplinary norms prevailed over the demands of one's supervisor - and the felt necessities of pursuing any given case.

To be sure, other factors (e.g., national and agency culture, the personalities of those involved) will mediate the impact of these design dynamics on the quality and quantity of outputs generated by the competition agency. But, it does not follow that one should ignore the significance of internal design features on the quality and quantity of those outputs.

\section{Procedural Fairness and Institutional Legitimacy}

Legitimacy is a fundamental attribute of any legal system worthy of the name - and procedural fairness is an important way to create and enhance legitimacy. The enforcement of a competition law entails several discrete tasks: the investigation of possible wrongdoing, the decision to prosecute, the determination of culpability, and the imposition of sanctions. In the design of a competition system, a jurisdiction can unbundle these functions, or combine them within a single entity.

Many countries unbundle decision-making tasks, using a "prosecutorial model." Under this approach, the competition agency makes the decision to investigate and to prosecute cases, but disputes are presented for decision to a separate entity/tribunal - sometimes courts of general jurisdiction, sometimes specialist competition law tribunals. The external tribunal also controls the decision to impose sanctions. Such unbundling is the rule when criminal sanctions are sought.

Conversely, the US FTC and the European Commission are examples of integration of these functions within a single entity. In the FTC, the board members control the decision to apply significant information gathering powers, the decision to issue complaints, and, ultimately, the determination (following an administrative trial before an administrative law judge) of culpability. Although adverse decisions may be appealed to independent courts, the judges are required to give deference to the FTC's administrative

Contributions to Law Enforcement, Research and Economic Knowledge and Policy: Bureau of Economics Contribution to Antitrust Enforcement 24-26 (September 4, 2003), available

http://www.ftc.gov/be/workshops/directorsconference/docs/directorstableGOOD.pdf\#page

$=17$. See also Willard F. Mueller, The Revival of Economics at the FTC in the 1960s, 25

Rev. Indus. Org. 91 (2004). 
determinations. The EC integrates these functions to an even higher degree than the FTC. The EC has authority to impose administrative fines (including fines of over $\$ 1$ billion in an abuse of dominance case against Intel) and to block mergers without recourse to an external judicial process.

The decision to unbundle or integrate involves tradeoffs between decision-making speed and expertise v. quality control and legitimacy. Tighter integration can accelerate investigation and resolution, by placing the key tasks in the hands of a body with specialized expertise. At the same time, integration can create difficulties with quality control problems, and also undermines procedural fairness.

The overall objective of any system is to generate substantively sound outcomes - but when all the relevant decisions are integrated into the same institution, it is more difficult for earlier decisions (including the decision to prosecute the case in the first instance) to be revisited. Instead, various bureaucratic pathologies increase the chances the case will simply run on auto-pilot, even if the original assessment was flawed, or circumstances have changed in the interim. Agencies can create internal safeguards to minimize such problems, including walling off the "case team" from the personnel that will ultimately decide issues of culpability, and requiring periodic "hard looks" at the evidence by those who are not already involved in the case. ${ }^{16}$

Those who are skeptical of the merits of any given lawsuit will not be impressed by such safeguards, and will emphasize the unfairness of having the same entity act as "judge, jury, and executioner" and deride the proceedings as a "kangaroo court." Notwithstanding the efficiencyenhancing benefits of integration, a nation that bundles prosecutorial and adjudicatory powers together is likely to incur real costs in the form of diminished perceptions of procedural fairness and legitimacy.

\section{Choosing From the Menu: What Can Be Done Going Forward?}

Now that we have laid out an array of choices that each country must make (whether explicitly or implicitly) in designing a competition agency, we turn to the ways in which the menu can assist individual jurisdictions interested in improving their institutional arrangements. We note three major applications.

First, for countries that have yet to adopt a competition law, the menu lays out the range of options and the consequences of various design choices. Instead of generic advice (i.e., "just copy [fill in the reader's preferred competition agency]"), countries can use the menu to make more nuanced and informed decisions when designing their own implementation

\footnotetext{
${ }^{16}$ Froeb, supra note 14 (discussing effect on competition agency decision-making of placing economists in separate organization unit).
} 
arrangements. Even if political imperatives make certain choices inevitable, and place other choices off-limits, the menu empowers the newly created competition authority with knowledge of the predictable consequences and trade-offs of those constrained choices. Stated differently, our menu provides the equivalent of the package insert that accompanies the dispensing of a prescription drug, listing various warnings and the known side effects.

What of jurisdictions that have already adopted competition laws? The last two decades have seen a precipitous increase in the number of countries with competition agencies - meaning that many countries have already chosen from among the nine design attributes enumerated in Part I. Countries made these choices for many reasons: to accommodate the desires of other countries or donor organizations, to satisfy national political imperatives, to deal with resource constraints (whether of personnel or tax revenues to fund the effort), and so on. These early design choices inevitably affect the perceived plausible choice set going forward. Stated differently, existing institutional arrangements create a status quo bias which constrains the possible alternatives - or at least creates political opposition to change, irrespective of the details of the proposal. Of course, this does not mean that countries are locked into existing institutional arrangements. Instead, there is actually considerable dynamism, as nations propose various design revisions in light of their own experiences and changing priorities. But, it does mean that there is likely to be opposition to any proposed reform, no matter its details.

Innovation in agency design for such countries is likely to proceed in three distinct stages: identification of weaknesses in existing arrangements; development of a reform proposal; and then a battle over whether to adopt the proposal. Our menu permits a more informed stock-taking of benefits and costs at each stage of this process. We should not expect a country to get everything right on the first try, any more than we would expect the first prototype of a new commercial airliner to be perfectly suited for full-scale production. Test flights enable an aerospace company to identify improvements that will make the production model a far superior aircraft. The only way to know how the prototype performs is to fly it. Similarly, the only way to understand the quality of a competition system design is to implement it. Quality improvement will not occur without a deliberate commitment to regular evaluation of system performance.

Finally, by structuring the analysis, the menu should facilitate benchmarking and performance comparisons across multiple jurisdictions. We now have enough history with the implementation of competition law that jurisdictions can build on the experiences of one another, instead of proceeding based on guess-work and hope. Sir Isaac Newton memorably 
observed that he was able to see further only by "standing on the shoulders of giants." Nations will enjoy similar benefits in deciding how to construct a new competition agency, or improve upon an existing regime.

\section{CONCLUSION}

Thomas Wolfe memorably observed "you can't go home again." But, when it comes to competition law, a country can and should periodically go home again - to revisit the origins of its existing arrangements and consider how to improve them. It is less important where a nation begins with its competition law than whether it seeks improvements over time. A habit of routine assessment and adjustment increases the likelihood that a jurisdiction will progress toward better (not best) performance and practice.

We hope that our menu will prove a useful tool in this process of continuous institutional refinement. We do not expect that the development and execution of improvements can or should take place rapidly. It often will take time to determine how a specific set of arrangements is performing. Patience is required, to assess whether any given institutional arrangement is up to the tasks it has been given. If the cycle of change is too short, we may never fully appreciate the strengths and weaknesses of any given design. The period of testing has to be long enough that we can make confident judgments about what has (and has not) worked.

Finally, it is important not to slight the costs of reorganizations and other makeovers of an existing institution. These adjustments are invariably disruptive, and do not always work. These costs and risks are likely to be smaller, and more likely to be worth incurring if they follow a process of patient experimentation, reflection, and benchmarking. Even if the demand for reorganization is driven by larger political and/or fiscal realities, there is almost always room for improving the process.

To complete our test flight metaphor, when it comes to agency design, a vertical ascent can easily be a precursor to a vertical plunge, followed shortly thereafter by a "controlled flight into terrain."." A vector of gradual cumulative improvement is likely to work out better for pilots, passengers, and the owners of the airline.

\footnotetext{
${ }^{17}$ See E.L. Wiener, Controlled Flight Into Terrain Accidents: System-Induced Errors, 19 Human Factors 171 (1977) ("controlled flight into terrain accidents are those in which an aircraft, under the control of the crew, is flown into terrain (or water) with no prior awareness on the part of the crew of the impending disaster.")
} 